\title{
INTEGRASI ANALYTIC HIERARCHY PROCESS DAN GOAL PROGRAMMING DALAM PEMILIHAN PEMASOK
}

\author{
ANNISA KESY GARSIDE DAN MARTINA JUAN KRISTIANDY \\ Jurusan Teknik Industri, Universitas Muhammadiyah Malang \\ Jl. Raya Tlogomas 246 Malang 65144 Jawa Timur \\ Laman: annisa_garside@yahoo.com,jk_martinanew@yahoo.co.id
}

\begin{abstract}
ABSTRAK
Pemilihan pemasok menjadi pertimbangan penting untuk meningkatkan efisiensi bagian pengadaan bahan baku mengingat biaya material dapat mencapai $70 \%$ dari biaya produk. Pemilihan pemasok seringkali merupakan permasalahan multi kriteria yang melibatkan faktor kualitatif dan kuantitatif. UD Virgo Snack Bersinar merupakan perusahaan pembuat keripik buah-buahan yang berlokasi di Malang. Perusahaan sering mengalami kekurangan pasokan buah nangka yang mengganggu jalannya proses produksi, sehingga perlu dilakukan pemilihan pemasok buah nangka secara selektif dengan mempertimbangkan kriteria-kriteria yang ditetapkan oleh perusahaan dan pengalokasian pesanan kepada supplier terpilih. Pada penelitian ini akan mengintegrasikan bobot pemasok dari hasil Analytic Hierarchy Process dengan model Preemptive Goal Programming untuk menentukan prioritas dan kuantitas pesanan kepada pemasok. Model diformulasikan untuk mencapai dua fungsi tujuan yaitu maksimasi total nilai pembelian dan minimasi total biaya pembelian serta mempertimbangkan batasan kapasitas pemasok dan pemenuhan kebutuhan buah nangka. Dari hasil running model goal programming diperoleh supplier dari Semarang akan memasok buah nangka sebanyak 7,5 ton pada periode November 2013 - Januari 2014 dan kekurangan pasokan untuk menutupi kebutuhan buah nangka dipasok oleh supplier dari Tajinan.
\end{abstract}

Kata kunci: buah nangka, pemasok, bobot pemasok, goal programming, analytic hierarchy process

\begin{abstract}
Considering that raw material cost could reach $70 \%$ of product cost, supplier selection process was become important consideration to improve the efficiency of procurement department. The supplier selection process was multi-criteria problem involving qualitative and quantitative factors. UD Virgo Bersinar was one of fruit chips manufacturer located in Malang. The company often experienced shortage of jackfruits which interrupt production process. Thus, it was necessary to choose its supplier by considering company's criteria and order allocation of selected supplier. This research would integrate supplier weight from Analytic Hierarchy Process and Preemptive Goal Programming model to determine priority of supplier and order quantity to the supplier. The model was formulated to achieve two objective functions, namely maximizing total value of purchasing and minimizing total cost of purchasing, by considering capacity of supplier and fulfillment of jackfruit. By running goal programming model, it was concluded that supplier from Semarang would supply 7.5 ton of jackfruit in November 2013-Januari 2014 and deficiency of needs would be supplied by supplier from Tajinan.
\end{abstract}

Keywords: jackfruit, supplier,supplier weight, goal programming, analytic hierarchy process

\section{PENDAHULUAN}

Pemilihan pemasok merupakan salah satu faktor yang harus diperhatikan oleh perusahaan karena peranan pemasok sangatlah penting dalam menjamin kelancaran produksi melalui pemenuhan bahan baku. Ongkos-ongkos material bisa mencapai antara 40\%-70\% dari ongkos sebuah produk akhir, sehingga pemilihan pemasok merupakan salah satu upaya efesiensi yang bisa dilakukan oleh bagian procurement (Pujawan, 2005). Menurut Ghodsypour dan O'Brien (1998), permasalahan pemilihan pemasok dapat diklasifikan menjadi 2 tipe. Pada tipe pertama, seorang pemasok mampu memenuhi semua 
kebutuhan pembeli (single sourcing). Sedangkan pada tipe kedua, tidak ada pemasok yang mampu memenuhi semua kebutuhan sehingga manajemen perusahaan harus memilih dan mengalokasikan order pada beberapa pemasok (multiple sourcing). Untuk menentukan pemasok mana yang dipilih merupakan problem yang tidak mudah karena melibatkan banyak kriteria kualitatif dan kuantitatif. Banyak sekali metode pemilihan yang dapat digunakan diantaranya Analytic Hierarchy Process (AHP), Analytic Network Process (ANP) , Data Envelopment Analysis (DEA), Fuzzy Sets Theory (FST), Genetic Algorithm (GA), Goal Programming (GP), Simple Multi-atribute Rating Technique (SMART), dan metode lainnya (Dahel, 2003).

UD Virgo Snack Bersinar merupakan perusahaan yang memproduksi keripik buahbuahan, diantaranya keripik apel, nangka, salak, nanas, dan rambutan. Hasil produksinya telah dipasarkan keseluruh Indonesia terutama di Jawa, Sumatera, Sulawesi dan Bali. Dari berbagai jenis keripik yang diproduksi, keripik nangka merupakan keripik yang paling digemari. Sehingga perusahaan membutuhkan pasokan buah nangka yang banyak. Saat ini UD Virgo telah memiliki beberapa pemasok yang memasok buah tersebut secara rutin. Meskipun telah memiliki sejumlah pemasok, perusahaan sering menghadapi kekurangan pasokan buah sehingga mengganggu jalannya proses produksi dan pembengkakan biaya pembelian untuk menutupi kekurangan tersebut. Beberapa hal yang menjadi penyebab kekurangan tersebut adalah kualitas buah nangka yang dikirim oleh pemasok tidak sesuai dengan yang ditetapkan, keterlambatan pengiriman dan jumlah pengiriman tidak tepat dengan yang dijanjikan. Oleh karena itu, perlu dilakukan pemilihan pemasok buah nangka secara selektif dengan mempertimbangkan banyak kriteria dan pengalokasian pesanan dengan mempertimbangkan multi objective functions untuk meminimasi resiko pembengkakan biaya pembelian bahan baku dan seringnya terjadi keterlambatan pengiriman bahan baku.
Penelitian yang membahas mengenai pemilihan pemasok telah banyak dilakukan diantaranya Ghodsypour and O'Brien (1998) mengusulkan sebuah metode dengan mengintegrasikan AHP dan Linier Programming (LP), Liu et al. (2000) menggunakan metode DEA, Kahraman et al. (2003) menggunakan pendekatan fuzzy AHP, Wang et al. (2004) mengintegrasikan AHP dan Preemptive Goal Programming (PGP), Shahanaghi dan Yazdian (2009) menggunakan TOPSIS, serta Garside dan Saputro (2011) menggunakan pendekatan fuzzy ANP yang diintegrasikan dengan goal programming. Penelitian ini akan menggunakan metodologi solusi yang dikembangkan oleh Wang et al. (2004), dimana AHP digunakan untuk penilaian pemasok berdasarkan sejumlah kriteria dan selanjutnya hasil penilaian tersebut menjadi koefisien fungsi tujuan pada model PGP untuk menentukan kuantitas order. Metode AHP dipilih dengan pertimbangan keputusan pemilihan pemasok melibatkan beberapa kriteria yang struktur hubungannya kompleks dan metodenya mudah dipahami. Selain itu, metode AHP telah banyak digunakan untuk memilih dan mengevaluasi pemasok, diantaranya Tahriri et al. (2008) dan Paksoy and Gules (2006). Dalam penelitian ini, penilaian pemasok menggunakan kriteria-kriteria berdasarkan hasil interview dengan pihak perusahaan, sedangkan Wang et al. (2004) menggunakan kriteria-kriteria berdasarkan metriks performansi dari model SCOR. Integrasi metode AHP dan PGP dalam pengambilan keputusan pemilihan pemasok pada UD Virgo diharapkan dapat menekan biaya pembelian bahan baku dan kebutuhan buah nangka terpenuhi sepanjang waktu.

\section{METODE}

Gambar 1 menunjukkan algoritma untuk pemilihan pemasok yang dikembangkan oleh Wang et al. (2004). Berdasarkan algoritma tersebut, maka tahapan yang dilakukan dalam penelitian ini dimulai dengan dekomposisi masalah menurut komponen-komponen utamanya 
yang terdiri dari tujuan, kriteria, sub kriteria dan alternatif (pemasok). Identifikasi kriteria dan sub kriteria dilakukan dengan interview ke bagian pembelian bahan baku. Sedangkan penentuan alternatif dilakukan dengan melihat data pemasok yang ada di perusahaan saat ini. Selanjutnya membuat struktur hirarki terdiri dari keseluruhan tujuan, kriteria, sub kriteria dan alternatif keputusan.

Setelah permasalahan didekomposisikan dan struktur hirarki diperoleh, dilanjutkan dengan menentukan tingkat kepentingan kriteria dan sub kriteria serta performansi alternatif/pemasok pada tiap sub kriteria. Dengan menggunakan metode AHP yang diusulkan Saaty (1993) maka penilaian dilakukan dengan perbandingan berpasangan dan kemudian diolah menjadi matriks perbandingan berpasangan. Dalam penelitian ini, penilaian dilakukan dengan memberikan kuisioner kepada pengambil keputusan yaitu bagian pembelian bahan baku UD.Virgo. Selanjutnya dilakukan perhitungan bobot kriteria dan sub kriteria dengan metode AHP yang diusulkan Saaty (1993).

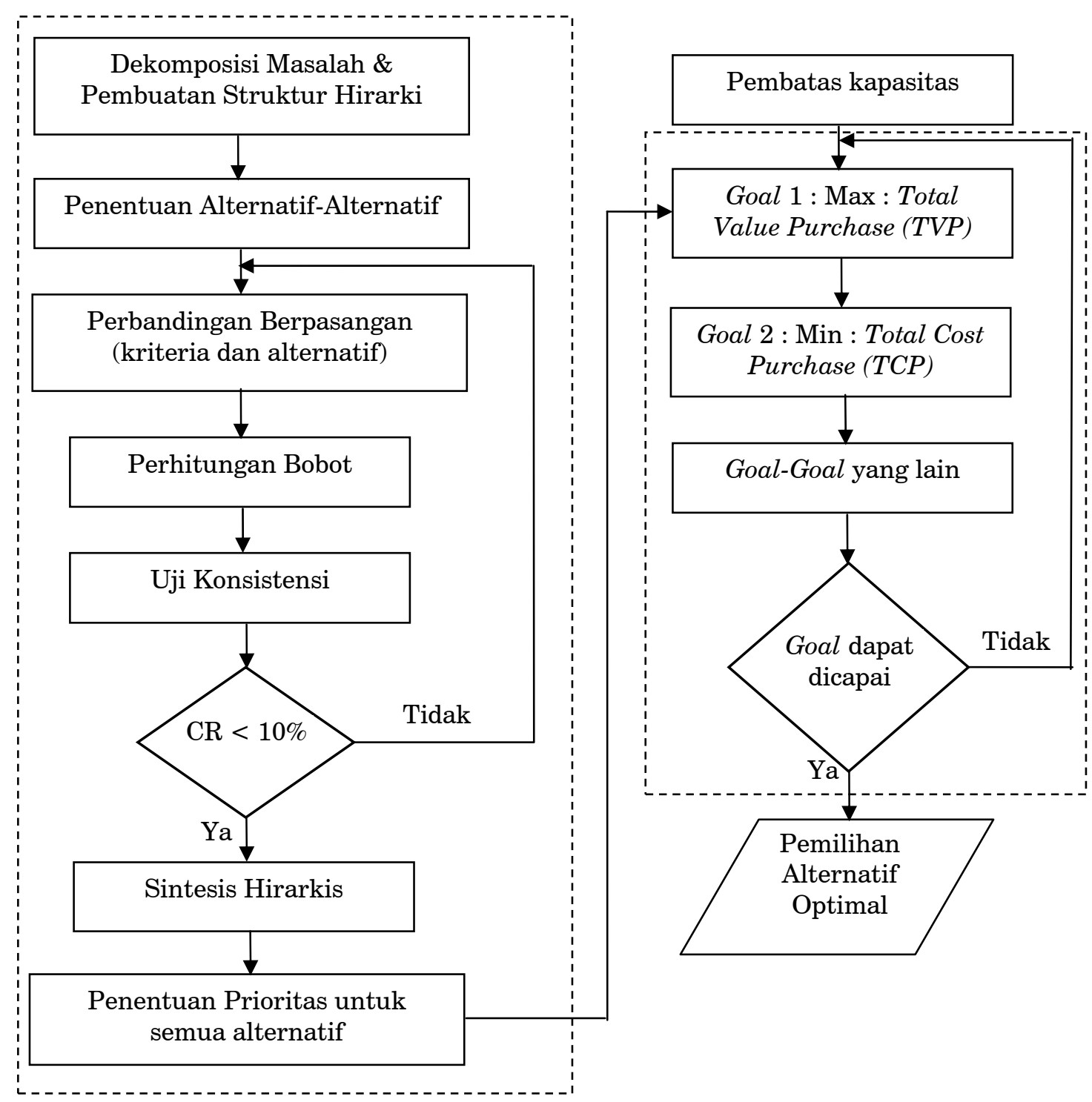

Gambar 1. Algoritma integrasi AHP-PGP untuk Pemilihan Pemasok Sumber : Wang et al. (2004) 
Tahap berikutnya melakukan uji konsistensi untuk memastikan bahwa pembuat keputusan telah memberikan penilaian yang konsisten. Jika nilai Consistency Ratio (CR) yang diperoleh kurang dari 0,1 maka dapat disimpulkan penilaian telah konsisten, sehingga tahapan dilanjutkan ke sintesis hirarki. Jika tidak, pengambil keputusan harus mengevaluasi kembali penilaian perbandingan berpasangan yang telah dilakukan. Sintesis hirarki merupakan tahap untuk menghitung skor akhir tiap pemasok dengan mengalikan bobot sub kriteria dan skor pemasok. Berdasarkan skor akhir tersebut, ditentukan ranking pemasok dimulai dari skor tertinggi sampai yang terendah.

Setelah melakukan penilaian pemasok dengan AHP maka dilanjutkan dengan formulasi model matematis untuk mengetahui pemasok terpilih dan kuantitas pesanan dengan mempertimbangkan batasan kapasitas, permintaan bahan baku dan biaya pembelian. Formulasi Model Preemptive Goal Programming (PGP) untuk pemilihan pemasok yang dikembangkan oleh Wang et al. (2004) sebagai berikut:

\section{Variabel keputusan}

$\mathrm{Q}_{\mathrm{x}}=$ kuantitas yang dibeli dari pemasok ke- $x$

$\mathrm{E}_{\mathrm{f}}=$ pencapaian diatas target dari goal ke- $f$

$\mathrm{U}_{\mathrm{f}}=$ pencapaian dibawah target dari goal ke- $f$

Dimana :

$\mathrm{x} \quad$ Indeks pemasok, $\mathrm{x}=1,2,3, \ldots \ldots, \mathrm{k}_{\mathrm{ij}}$

$\mathrm{f} \quad$ indeks untuk goal (prioritas), $\mathrm{f}=1,2,3, \ldots \ldots \mathrm{F}$

\section{Parameter}

$\mathrm{T}_{\mathrm{ij}} \quad$ Permintaan konsumen untuk komponen $j$ pada produk $i$

TVP Total nilai pembelian

TCP Total biaya pembelian

$\mathrm{D}_{\mathrm{x}} \quad$ Biaya pembelian per unit dari pemasok ke- $x$

$\mathrm{R}_{\mathrm{x}} \quad$ Kapasitas produksi dari pemasok ke- $x$

F Jumlah goal (prioritas)

$\mathrm{K}_{\mathrm{ij}} \quad$ Total jumlah dari alternatif potensial untuk komponen $j$ pada produk $i$

$\mathrm{W}_{\mathrm{x}} \quad$ Skor akhir/bobot dari pemasok ke- $x$ (dari penilaian dengan metode AHP)

\section{Fungsi Pembatas}

$\mathrm{Rx} \geq \mathrm{Qx}$

$\mathrm{Qx} \geq 0$

$\sum_{\mathrm{x}=1}^{\mathrm{kij}} \mathrm{Q}_{\mathrm{x}}=\mathrm{T}_{\mathrm{j}}$

\section{Fungsi Preemptive Priorities/Goals}

Prioritas 1 : Maksimasi TVP

$\sum_{\mathrm{x}=1}^{\mathrm{kij}} \mathrm{W}_{\mathrm{x}} \mathrm{Q}_{\mathrm{x}}+\mathrm{U}_{1}-\mathrm{E}_{1}=\mathrm{TVP}$

Prioritas 2 : Minimasi TCP

$\sum_{\mathrm{x}=1}^{\mathrm{kij}} \mathrm{D}_{\mathrm{x}} \mathrm{Q}_{\mathrm{x}}+\mathrm{U}_{2}-\mathrm{E}_{2}=\mathrm{TCP}$

\section{Fungsi Minimasi Penyimpangan Goal}

$\mathrm{P} 1$ : $\min \mathrm{U} 1$

$\mathrm{P} 2: \min \mathrm{E} 2$

Berdasarkan formulasi tersebut, tahap berikutnya adalah mencari solusi optimal dengan menggunakan software WinQSB. Solusi optimal yang diputuskan meliputi : pemasok yang terpilih untuk memasok, berapa banyak bahan baku dipasok dari pemasok tersebut dan apakah kedua tujuan yang telah ditetapkan tercapai atau tidak targetnya.

\section{HASIL DAN PEMBAHASAN}

UD Virgo Snack Bersinar mempunyai beberapa pemasok untuk memasok buah nangka. Pemasok ini merupakan pengepul buah nangka di daerahnya. Diantaranya pengepul di daerah Tajinan-Malang, Buring-Malang dan Semarang. Pengambilan buah nangka dari pengepul di daerah Tajinan dan Buring dilaksanakan tiap hari sedangkan di daerah Semarang dilaksanakan 3 hari sekali. Masing-masing pengepul memiliki kemampuan memasok sebesar 7,5 ton per bulan untuk pengepul di daerah Tajinan, 7,8 ton per bulan untuk pengepul dari Buring dan 7,5 ton per bulan untuk pengepul dari Semarang. Sedangkan harga yang ditawarkan oleh kedua pengepul dari Malang sebesar Rp 2400 per kilo dan Rp 2100 untuk pengepul dari Semarang. 
Berdasarkan hasil wawancara dengan bagian pembelian bahan baku UD Virgo Snack Bersinar diperoleh kriteria dan sub kriteria yang digunakan sebagai dasar pemilihan pemasok buah nangka adalah:

1. Kualitas

Kualitas buah nangka dilihat dari rasa, ketebalan daging dan tingkat kematangan buah. Buah nangka yang berkualitas memiliki rasa manis dengan warna kuning kemerahan dan bau menyengat. Ketebalan dagingnya tergantung dari jenis buahnya dan daerah tanam. Sedang tingkat kematangan ditentukan oleh penampilan fisik dan umur buah saat panen.

\section{Biaya}

Biaya bahan baku yang dimaksud terdiri dari biaya pembelian bahan baku dan ongkos kirim. Biaya pembelian bahan baku nangka dihitung rupiah per kilogram. Ongkos kirim merupakan biaya yang dikeluarkan saat pengambilan material, termasuk bahan bakar, honor supir dan biaya lainnya.

3. Pengiriman

Dalam kriteria pengiriman terbagi menjadi lead time dan ketepatan waktu. Lead time adalah rentang waktu antara pemesanan dengan kedatangan barang yang dipesan. Dikarenakan UD Virgo memproduksi makanan maka buah nangka yang dipesan harus segera datang dan diproduksi. Ketepatan waktu pengiriman juga penting, karena jika bahan baku datang terlambat maka pabrik tidak dapat produksi dan pekerja libur.

Gambar 2 menunjukkan struktur hierarki yang menggambarkan kriteria, sub kriteria dan alternatif pemasok yang ada saat ini. Dengan menggunakan struktur hierarki tersebut, dilakukan penilaian tingkat kepentingan antar kriteria dan antar sub kriteria secara perbandingan berpasangan dengan memberikan kuisioner kepada bagian pembelian bahan baku UD Virgo. Selanjutnya dilakukan perhitungan bobot kepentingan menggunakan software expert choice dan diperoleh bobot kriteria dan sub kriteria seperti ditunjukkan pada Tabel 1. Nilai CR yang diperoleh dari uji konsistensi kurang dari 0,1 sehingga disimpulkan penilaian pada kuisioner telah konsisten.

Semakin besar bobot suatu kriteria maka

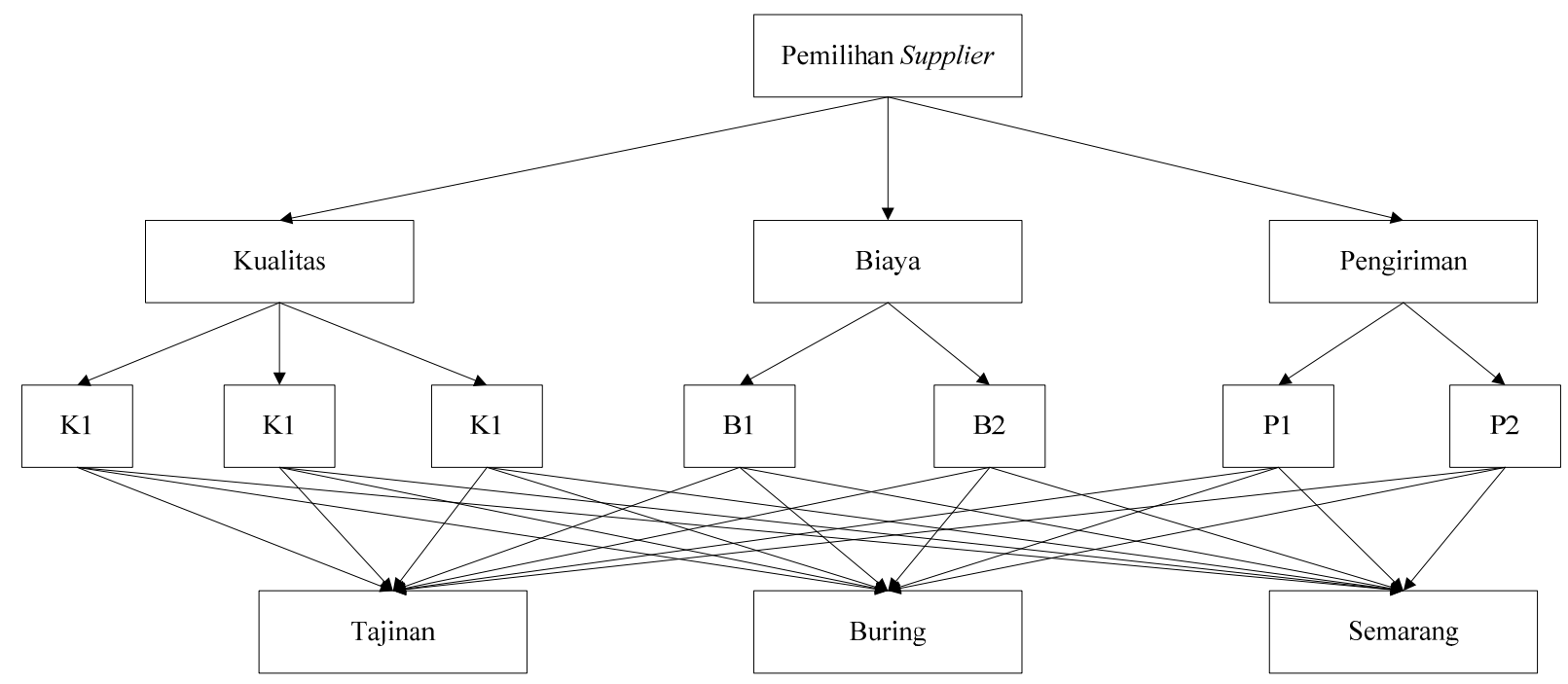

Gambar 2. Struktur Hierarki Pemilihan Pemasok di UD Virgo Snack Bersinar

Keterangan :

$\mathrm{K} 1$ = Rasa buah

$\mathrm{K} 2=$ Ketebalan daging

K3 = Tingkat kematangan

B1 = Harga bahan baku
B2 $=$ Ongkos kirim

$\mathrm{P} 1=$ Lead time

$\mathrm{P} 2=$ Ketepatan waktu 
Tabel 1. Perhitungan bobot kriteria dan sub kriteria

\begin{tabular}{lclc}
\hline \multicolumn{1}{c}{ Kriteria } & Bobot Kriteria & \multicolumn{1}{c}{ Sub Kriteria } & Bobot Sub Kriteria \\
\hline Kualitas & \multirow{2}{*}{0,559} & rasa buah & 0,634 \\
& & Ketebalan daging & 0,192 \\
& & Tingkat kematangan & 0,174 \\
\multirow{2}{*}{ Biaya } & \multirow{2}{*}{0,352} & Harga bahan baku & 0,875 \\
& \multirow{2}{*}{ Pengiriman } & Ongkos kirim & 0,125 \\
& \multirow{2}{*}{0,089} & lead time & 0,250 \\
& & ketepatan waktu & 0,750 \\
\hline
\end{tabular}

semakin besar pengaruh kriteria tersebut dalam proses pemilihan pemasok. Berdasarkan Tabel 1 dapat dilihat bahwa bobot terbesar terdapat pada kriteria kualitas dengan bobot 0,559 . Prioritas kedua adalah kriteria biaya dengan bobot 0,352 . Biaya dianggap penting dikarenakan biaya yang tinggi akan mengakibatkan pembengkakan biaya produksi. Sedangkan kriteria pengiriman menempati prioritas ketiga dengan bobot 0,089 .

Pada kriteria kualitas, sub kriteria rasa memiliki bobot terbesar yaitu sebesar 0,634. Bobot sub kriteria rasa memiliki bobot yang lebih tinggi dibandingkan dengan dua sub kriteria yang lain dikarenakan rasa buah nangka yang manis merupakan keinginan konsumen kripik nangka. Supply buah nangka yang memiliki rasa manis juga mengurangi penggunaan pemanis buah sebagai penambah rasa manis. Sedangkan sub kriteria tingkat kematangan buah nangka mendapatkan bobot terkecil yang menunjukkan bahwa sub kriteria ini menempati prioritas terbawah dalam pemilihan kualitas buah nangka di UD Virgo Snack Bersinar. Pada kriteria biaya, sub kriteria harga bahan baku mempunyai prioritas pertama dengan bobot sebesar 0,875. dan ongkos kirim menempati urutan kedua dengan bobot 0,125 . Hal ini menunjukkan perusahaan lebih mementingkan harga bahan baku dibandingkan ongkos kirim. Pada kriteria pengiriman, perusahaan lebih mementingkan ketepatan waktu dibandingkan lead time. Ketepatan waktu menjadi pertimbangan lebih besar dikarenakan keterlambatan bahan
Tabel 2. Bobot masing-masing pemasok

\begin{tabular}{clc}
\hline No & Pemasok & Bobot \\
\hline 1 & Semarang & 0,577 \\
2 & Tajinan & 0,277 \\
3 & Buring & 0,195 \\
\hline
\end{tabular}

baku akan mempengaruhi pelaksanaan proses produksi

Penilaian pemasok dilakukan dengan cara membandingkan kinerja masing-masing pemasok pada masing-masing sub kriteria. Penilaian tersebut dilakukan dengan cara yang sama dalam menentukan bobot kriteria dan sub kriteria. Responden memberikan penilaian dan mengisi matriks perbandingan berpasangan pada kuisioner. Selanjutnya dilakukan pengolahan dengan software Expert Choice dan hasilnya dapat dilihat pada Tabel 2. Bobot pemasok dari Semarang, Tajinan dan Buring masingmasing sebesar 0,577; 0,277 dan 0,195. Pemasok Semarang memiliki bobot tertinggi sehingga diprioritaskan menjadi pemasok buah nangka untuk UD. Virgo Snack Bersinar.

Kebutuhan buah nangka untuk produksi keripik pada bulan November 2013 - Januari 2014 diperkirakan sebesar 7,9 ton; 8,5 ton dan 8,15 ton. Pemasok dari Semarang tidak bisa memenuhi seluruh kebutuhan tersebut karena hanya mampu memasok sebesar 7,5 ton per bulannya, sehingga terdapat kendala yang berhubungan dengan kapasitas pengiriman oleh pemasok. Oleh 
karena itu, pengambilan keputusan dilanjutkan dengan membuat formulasi Preemptive Goal Programming (PGP). Integrasi AHP dengan PGP dilakukan dengan menggunakan bobot pemasok dari perhitungan AHP sebagai koefisien fungsi tujuan total nilai pembelian dalam model PGP. Dari hasil wawancara dengan pemilik UD Virgo, perusahaan menargetkan bahwa total biaya pembelian buah nangka tidak melebihi Rp16.710.000, Rp 18.150.000, dan Rp 17.310.000 untuk bulan November 2013 - Januari 2014. Sedangkan total nilai pembelian minimum memenuhi $50 \%$ dari permintaan pada tiap bulannya.

Formulasi PGP untuk pemilihan pemasok pada bulan November 2013 dinyatakan sebagai berikut:

\section{Variabel Keputusan}

$\mathrm{q}_{\mathrm{x}}=$ kuantitas pembelian buah nangka $(\mathrm{kg})$ dari pemasok ke-x, $x=1,2$, dan 3

$\mathrm{e}_{\mathrm{f}}=$ pencapaian di atas target dari tujuan ke-f, $\mathrm{f}=1$ dan 2

$\mathrm{u}_{\mathrm{f}}=$ pencapaian di bawah target dari tujuan ke- $f, f=1$ dan 2

\section{Fungsi kendala}

$\mathrm{q}_{1} \leq 7500$

$\mathrm{q}_{2} \leq 7800$

$\mathrm{q}_{3} \leq 7500$

$\mathrm{q}_{1}+\mathrm{q}_{2}+\mathrm{q}_{3}=7900$

Pembatas 8 sampai 10 memastikan bahwa kuantitas pembelian buah nangka dari pemasok Tajinan, Buring dan Semarang tidak melebihi kapasitas pasokan perbulannya. Sebagai contoh pembatas 8 menjamin bahwa kuantitas pembelian buah nangka dari pemasok ke-1 yaitu pemasok dari Tajinan tidak melebihi kapasitas pasokannya yaitu sebesar 7,5 ton atau $7500 \mathrm{~kg}$. Sedangkan pembatas 11 menjamin bahwa kebutuhan buah nangka pada bulan November 2013 sebesar 7,9 ton atau $7900 \mathrm{~kg}$ dapat terpenuhi.

Sesuai dengan permasalahan yang dihadapi perusahaan yaitu pembengkakan biaya pembelian maka prioritas tujuan pertama dalam model PGP adalah meminimalkan total biaya pembelian agar tidak melebihi target biaya pembelian yang telah ditetapkan oleh UD Virgo sebesar Rp16.710.000 pada bulan November 2013. Selanjutnya prioritas tujuan kedua bertujuan untuk memaksimalkan total nilai pembelian sehingga minimum permintaan/kebutuhan perusahaan dapat dicapai dari pemasok yang terpilih seperti ditunjukkan pada persamaan 13 .

\section{Fungsi Preemptive Priorities/Tujuan}

Prioritas 1 : Maksimasi Total Biaya Pembelian $2400 \mathrm{q}_{1}+2400 \mathrm{q}_{2}+2100 \mathrm{q}_{3}+\mathrm{u}_{1}-\mathrm{e}_{1}=16710000$

Prioritas 2 : Minimasi Total Nilai Pembelian $0,277 \mathrm{q}_{1}+0,195 \mathrm{q}_{2}+0,577 \mathrm{q}_{3}+\mathrm{u}_{2}-\mathrm{e}_{2}=3800 \ldots$.

Nilai sisi kiri pada persamaan 12 menunjukkan biaya pembelian pada masingmasing pemasok diperoleh dengan mengalikan harga buah nangka yang ditawarkan oleh pemasok tersebut dengan kuantitas pembeliannya.Nilai sisi kiri pada persamaan 13 menunjukkan bahwa total nilai pembelian diperoleh dengan mengalikan bobot masing-masing pemasok dengan kuantitas pembelian buah nangka dari pemasok tersebut. Sementara itu, nilai sisi kanan diperoleh berdasarkan target perusahaan yaitu sebesar 50\% dari permintaan buah nangka pada bulan November 2013 yaitu 3,8 ton atau $3800 \mathrm{~kg}$. Kedua prioritas tujuan tersebut akan tercapai dengan cara meminimalkan penyimpangan yang terjadi dengan merumuskan fungsi minimasi penyimpangan tujuan yang dinyatakan pada persamaan 14 dan 15 .

\section{Fungsi Minimasi Penyimpangan Tujuan}

Tujuan Prioritas 1 : minimasi $\mathrm{e}_{1}$ Tujuan Prioritas 2 : minimasi $\mathrm{u}_{2}$

Penyelesaian model PGP untuk pemilihan pemasok buah nangka pada bulan November 2013 dibantu dengan software WinQSB dan hasilnya ditunjukkan pada Gambar 3. Dari hasil running diperoleh solusi $\mathrm{q}_{1}$ sebesar $400, \mathrm{q}_{3}$ sebesar $7500, \mathrm{u}_{1}$, $\mathrm{u}_{2}$ dan $\mathrm{e}_{1}$ sama dengan 0 serta $\mathrm{e}_{2}$ sebesar 638,30. 


\begin{tabular}{|c|c|c|c|c|c|c|c|c|c|}
\hline & $21: 24: 34$ & & Thursday & August & 01 & 2013 & & & \\
\hline & $\begin{array}{l}\text { Goal } \\
\text { Level }\end{array}$ & $\begin{array}{l}\text { Decision } \\
\text { Variable }\end{array}$ & $\begin{array}{c}\text { Solution } \\
\text { Value }\end{array}$ & $\begin{array}{l}\text { Unit Cost or } \\
\text { Profit c(i) }\end{array}$ & $\begin{array}{c}\text { Total } \\
\text { Contribution }\end{array}$ & $\begin{array}{l}\text { Reduced } \\
\text { Cost }\end{array}$ & $\begin{array}{l}\text { Allowable } \\
\text { Min. c(i) }\end{array}$ & $\begin{array}{l}\text { Allowable } \\
\text { Max. c(i) }\end{array}$ & \\
\hline 1 & G1 & q1 & 400.00 & 0 & 0 & 0 & -300.00 & 0 & \\
\hline 2 & G1 & q2 & 0 & 0 & 0 & 0 & 0 & $M$ & \\
\hline 3 & G1 & q3 & $7,500.00$ & 0 & 0 & 0 & 0 & 300.00 & \\
\hline 4 & G1 & u1 & 0 & 0 & 0 & $\mathbf{0}$ & 0 & $M$ & \\
\hline 5 & G1 & e1 & 0 & 1.00 & 0 & 1.00 & 0 & $M$ & \\
\hline 6 & G1 & u2 & 0 & 0 & 0 & 0 & 0 & $M$ & \\
\hline 7 & G1 & e2 & 638.30 & 0 & 0 & $\mathbf{0}$ & 0 & $\mathbf{0}$ & \\
\hline 8 & G2 & $q 1$ & 400.00 & 0 & 0 & $\mathbf{0}$ & $-M$ & 0 & \\
\hline 9 & G2 & q2 & 0 & 0 & 0 & 0 & 0 & $M$ & \\
\hline 10 & G2 & q3 & $7,500.00$ & 0 & $\mathbf{0}$ & 0 & 0 & $M$ & \\
\hline 11 & G2 & u1 & 0 & 0 & $\mathbf{0}$ & 0 & 0 & $M$ & \\
\hline 12 & G2 & e1 & 0 & 0 & 0 & 0 & $-M$ & $M$ & \\
\hline 13 & G2 & u2 & 0 & 1.00 & $\mathbf{0}$ & 1.00 & 0 & $M$ & \\
\hline \multirow[t]{5}{*}{14} & G2 & e2 & 638.30 & 0 & $\mathbf{0}$ & 0 & 0 & 0 & \\
\hline & G1 & Goal & Value & [Min. $]=$ & 0 & (Alternate & Solution & Exists!!] & \\
\hline & G2 & Goal & Value & [Min.] $=$ & 0 & & & & \\
\hline & & & & & & & & & \\
\hline & Constraint & $\begin{array}{l}\text { Left Hand } \\
\text { Side }\end{array}$ & Direction & $\begin{array}{l}\text { Right Hand } \\
\text { Side }\end{array}$ & $\begin{array}{c}\text { Slack } \\
\text { or Surplus }\end{array}$ & $\begin{array}{l}\text { Allowable } \\
\text { Min. RHS }\end{array}$ & $\begin{array}{l}\text { Allowable } \\
\text { Max. RHS }\end{array}$ & $\begin{array}{c}\text { ShadowPrice } \\
\text { Goal } 1\end{array}$ & $\begin{array}{c}\text { ShadowPrice } \\
\text { Goal } 2\end{array}$ \\
\hline 1 & C1 & 400.00 & $<=$ & $7,500.00$ & $7,100.00$ & 400.00 & M & 0 & 0 \\
\hline 2 & C2 & 0 & $<=$ & $7,800.00$ & $7,800.00$ & 0 & $M$ & $\mathbf{0}$ & $\mathbf{0}$ \\
\hline 3 & C3 & $7,500.00$ & $<=$ & $7,500.00$ & 0 & $7,500.00$ & $M$ & $\mathbf{0}$ & $\mathbf{0}$ \\
\hline 4 & C4 & $7,900.00$ & $=$ & $7,900.00$ & $\mathbf{0}$ & $7,661.56$ & $7,900.00$ & $\mathbf{0}$ & 0 \\
\hline 5 & C5 & $16,710,000.00$ & $=$ & $16,710,000.00$ & 0 & $16,710,000.00$ & $17,348,300.00$ & 0 & 0 \\
\hline 6 & C6 & $3,800.00$ & $=$ & $3,800.00$ & $\mathbf{0}$ & $-H$ & $4,438.30$ & $\mathbf{0}$ & $\mathbf{0}$ \\
\hline
\end{tabular}

Gambar 3. Hasil running model PGP pemilihan pemasok buah nangka pada bulan November 2013 dengan software WinQSB

Berdasarkan hasil tersebut maka pemasok buah memasok $7500 \mathrm{~kg}$. Kedua prioritas tujuan telah nangka dari Tajinan harus memasok $400 \mathrm{~kg}$ dan tercapai karena nilai penyimpangan $\mathrm{e}_{1}$ dan $\mathrm{u}_{2}$ pemasok buah nangka dari Semarang harus berharga sama dengan 0 .

Tabel 3. Hasil keputusan pemilihan pemasok nangka

Pemasok

Hasil AHP dan PGP

\section{Bobot Pemasok Kuantitas Keputusan Akhir Pembelian (kg)}

\begin{tabular}{lccl}
\hline November 2013 & & $\begin{array}{l}\text { Pemasok dari Semarang memasok } \\
\text { Semarang }\end{array}$ & $7500 \mathrm{~kg}$ dan sisanya di pasok \\
Tajinan & 0,577 & 400 & pemasok dari Tajinan sebesar 400 kg \\
Buring & 0,277 & & \\
\hline $\begin{array}{l}\text { Desember 2013 } \\
\text { Semarang }\end{array}$ & & & $\begin{array}{l}\text { Pemasok dari Semarang memasok } \\
\text { Temon kg dan sisanya di pasok }\end{array}$ \\
Tajinan & 0,577 & 7500 & pemasok dari Tajinan sebesar 1000 \\
Buring & 0,277 & 1000 & $\mathrm{~kg}$ \\
\hline
\end{tabular}




\begin{tabular}{lccl}
\hline Januari 2014 & & Pemasok dari Semarang memasok \\
Semarang & 0,577 & 7500 & 7500 kg dan sisanya di pasok \\
Tajinan & 0,277 & 650 & pemasok dari Tajinan sebesar 650 kg \\
Buring & 0,195 & & \\
\hline
\end{tabular}

Formulasi Model PGP selanjutnya dilakukan untuk bulan Desember 2013 dan Januari 2014 dengan menyesuaikan data permintaan dan target pencapaian tujuan pada kedua bulan tersebut. Hasil penyelesaian model PGP untuk pemilihan pemasok buah nangka pada bulan November 2013 - Januari 2014 sebagai berikut :

Dari Tabel 3 dapat dilihat bahwa pemasok yang terpilih untuk memasok buah nangka pada Bulan November 2013 - Januari 2014 adalah pemasok dengan bobot tertinggi pertama dan kedua yaitu pemasok dari Semarang dan Tajinan. Pemasok dari Semarang adalah pemasok dengan kualitas buah nangka lebih baik dari pemasok lain, karena dilihat dari sub kriteria memiliki rasa buah lebih manis dengan warna buah kemerahan dan daging yang tebal. Selain itu, pemasok dari Semarang juga menawarkan harga yang lebih rendah dibandingkan kedua pemasok yang lainnya. Berdasarkan kelebihan yang dimiliki pemasok dari Semarang tersebut maka penyelesaian model PGP menunjukkan kuantitas pembelian dari pemasok Semarang dimaksimalkan sebesar kapasitas pasokannya yaitu $7500 \mathrm{~kg}$ per bulan. Selanjutnya kekurangan untuk menutupi kebutuhan buah nangka diambil dari pemasok Tajinan yang mempunyai bobot tertinggi kedua. Pemasok dari Tajinan lebih dipilih untuk memasok buah nangka daripada pemasok dari Buring karena memiliki bobot penilaian yang lebih besar meskipun kedua pemasok menawarkan harga yang sama.

\section{SIMPULAN}

Integrasi AHP dengan model PGP digunakan dalam situasi terdapat batasan kapasitas pemasok pada saat pemilihan pemasok. Untuk mendapatkan keputusan yang valid maka perbandingan berpasangan pada penilaian kriteria, sub kriteria dan alternatif harus dilakukan oleh manajer yang memiliki pengetahuan yang cukup tentang supplier dan performansinya. Hal ini dikarenakan hasil penilaian tersebut akan dijadikan koefisien fungsi tujuan pada model PGP sehingga hasilnya akan mempengaruhi pencapaian solusi kuantitas pesanan. Penerapan integrasi AHP dan model PGP di UD Virgo Snack Bersinar menghasikan keputusan pemasok dari Semarang akan memasok sebesar 7,5 ton pada bulan November 2013 - Januari 2014 dan pemasok dari Tajinan akan memasok sebesar 0,4; 1 dan 0,65 ton selama tiga bulan tersebut. Penelitian lanjutan dapat dilakukan dengan mengembangkan integrasi AHP dengan model PGP ini menjadi sistem pendukung keputusan yang akan memberikan kemudahan dalam pemilihan pemasok sesuai dengan yang diharapkan.

\section{DAFTAR PUSTAKA}

Dahel, N.E. 2003. Vendor Selection and Order Quantity Allocation in Volume Discount Environments. Supply Chain Management: An International Journal, 8 (4), pp. 335-342.

Garside, A.K. dan Saputro, T.E. 2011. Integrasi Fuzzy-ANP dan Goal Programming dalam Pemilihan Supplier dan Alokasi Order (Studi Kasus : PT. Petrokimia Gresik), Prosiding Seminar Nasional Teknik Industri dan Kongres BKSTI VI.

Ghodsypour, S.H. dan O'Brien, C. 1998. Decision Support System for Supplier Selection Using an Integrated Analytic Hierarchy Process and Linear Programming, International Journal of Production Economics, 56-57, 199-212. 
Kahraman, C., Cebeci, U., and Ulukan, Z. 2003. Multi-Criteria Supplier Selection Using Fuzzy AHP. Logistics Information Management, 16, pp. 382-394.

Liu, J., Ding, F.-Y., and Lall, V. 2000. Using Data Envolopment Analysis to Compare Suppliers for Supplier Selection and Performance Improvement. Supply Chain Management: An International Journal, 5 (3), pp. 143150.

Paksoy, T., and Gules, H.K., 2006. Analytic Hierarchy Process for Supplier Selection Problem in Supply Chain Management: case Study of A Textile Manufacturer Firm, Sigma, 4, 100-109.

Saaty, T.L., 1993. Pengambilan Keputusan Bagi Para Pemimpin: Proses Hirarki Analitik untuk Pengambilan Keputusan dalam
Situasi yang Kompleks, PT Pustaka Binaman Pressindo, Jakarta.

Shahanaghi, K. and Yazdian, S. A. 2009. Vendor Selection Using a New Fuzzy Group TOPSIS Approach. Journal of Uncertain Systems, 3 (3), pp. 221-231.

Tahriri, F., Osman, M. Rasid, Ali, A., Yusuff, R.M., and Espandiary, A., 2008. AHP Approach for Supplier Evaluation and Selection in Steel Manufacturing Company, Journal of Industrial Engineering and Management, 01 (02), 54-76.

Wang, G., Huang, S.H. and Dismukes, J.P., 2004. Product-Driven Supply Chain Selection Using Integrated Multi-Criteria Decision Making Mehodology, International Journal of Production Economics, 91, pp. 1-15. 